\title{
Primary Epstein-Barr virus infection shortly after primary Cytomegalovirus infection: a case report
}

\author{
Katsumasa Koyama', Takatoshi Anno ${ }^{1 *} \mathbb{0}$, Takashi Urano ${ }^{1}$, Ryo Shigemoto', Shintaro Irie ${ }^{1}$, Fumiko Kawasaki ${ }^{1}$, \\ Miwa Kawanaka², Hirofumi Kawamoto², Hideaki Kaneto ${ }^{3}$ and Koichi Tomoda ${ }^{1}$
}

\begin{abstract}
Background: Infectious mononucleosis (IM) and mononucleosis-like illnesses are common viral infectious diseases which are often accompanied by a high fever, pharyngitis and lymphadenopathy in adults, although such infection in childhood is generally subclinical. Most cases of IM are caused by the Epstein-Barr virus (EBV) or Cytomegalovirus $(C M V)$. However, it is difficult to diagnose IM only with subjective symptoms, and thus EBV and CMV are nearly indistinguishable in clinical practice.
\end{abstract}

Case presentation: A 20-year-old healthy Japanese woman had a 2-day history of high fever and consulted us. She had sex for the first time 6 months earlier. Her virus antibodies showed that she was infected with primary CMV. About 5 months later, she again experienced high fever and lymph node enlargement at the posterior cervical region. Her virus antibodies showed that she was infected with primary EBV at that time.

Conclusion: Herein, we report a healthy adult Japanese woman with primary EBV infection relatively soon after primary CMV infection. It is very interesting to compare the symptoms and/or clinical data after EBV and CMV infection in the same patient within a short period of time. Our patient was diagnosed based only on subjective symptoms, physical examination and laboratory data, without tests of such virus-related antibodies. Therefore, clinicians should bear in mind that primary EBV infection and/or primary CMV infection is possible when patients have symptoms such as high fever, pharyngitis and lymphadenopathy, even in healthy adults.

Keywords: Primary Cytomegalovirus infection, Primary Epstein-Barr virus infection, In a short period, Healthy adult Japanese woman

\section{Background}

Infectious mononucleosis (IM) and mononucleosis-like illnesses (MLI) are common viral infectious diseases that are typically observed in childhood. After such infection, children are generally subclinical but adults often experience serious symptoms such as a high fever, pharyngitis and lymphadenopathy $[1,2]$. Most cases of IM are caused

\footnotetext{
*Correspondence: anno-t@umin.ac.jp

1 Department of General Internal Medicine 1, Kawasaki Medical School,

2-6-1 Nakasange, Kita-ku, Okayama 700-8505, Japan

Full list of author information is available at the end of the article
}

by the Epstein-Barr virus (EBV) or Cytomegalovirus $(\mathrm{CMV})$. It was reported that younger age, shorter interval from the onset to hospital visit, cervical lymphadenopathy, tonsillar white coat, hepatosplenomegaly or atypical lymphocytosis differentiates IM caused by EBV from that by CMV [3]. It was also shown that moderate elevation of lactate dehydrogenase and $\gamma$-glutamyl transpeptidase $(\gamma-$ GTP) also differentiates IM caused by EBV from that by CMV [3]. In clinical practice, however, since it is difficult to diagnose IM and MLI only with subjective symptoms, EBV and CMV are nearly indistinguishable $[4,5]$. In this context, serological testing for IM and original author(s) and the source, provide a link to the Creative Commons licence, and indicate if changes were made. The images or other third party material in this article are included in the article's Creative Commons licence, unless indicated otherwise in a credit line to the material. If material is not included in the article's Creative Commons licence and your intended use is not permitted by statutory regulation or exceeds the permitted use, you will need to obtain permission directly from the copyright holder. To view a copy of this licence, visit http://creativecommons.org/licenses/by/4.0/. The Creative Commons Public Domain Dedication waiver (http://creativeco mmons.org/publicdomain/zero/1.0/) applies to the data made available in this article, unless otherwise stated in a credit line to the data. 
MLI is important, but it requires several days to obtain the results. Moreover, EBV-specific antibody tests sometimes produce inaccurate results such as false negatives $[6,7]$ and cross-reactivity with CMV [8].

Herein, we report a healthy adult Japanese woman with primary EBV infection shortly after primary CMV infection. It is very interesting to compare the symptoms and/ or clinical data after EBV and CMV infection in the same patient within a short period.

\section{Case presentation}

A 20-year-old healthy Japanese woman had a 2-day history of high fever and consulted the emergency room in Kawasaki Medical School. There was no significant past medical history except for mycoplasma pneumonia at the ages of 1 and 18. She had sex for the first time 6 months earlier. She had erythema in the pharynx and lymph node enlargement at the posterior cervical and left axillary region, but there were no findings on physical and neurological examination. Her chest sounds were clear, and she had no cough. The tips of the liver and spleen were not palpable. Her vital signs were as follows: heart rate 108 beats/minute, blood pressure 101/58 mmHg, and temperature $38.9^{\circ} \mathrm{C}$. Table 1 shows the laboratory data on admission. Leukocytopenia and increased C-reactive protein (CRP) were observed: white blood cell (WBC) count, $1710 / \mu \mathrm{L}$ (neutrophils 76.0\%; monocytes 5.0\%; lymphocytes $18.0 \%$; atypical lymphocytes $1.0 \%$ ); CRP, $3.92 \mathrm{mg} / \mathrm{dl}$. She had mild liver dysfunction: $\gamma$-GTP, $78 \mathrm{U} / \mathrm{L}$; alkaline phosphatase (ALP), $276 \mathrm{U} / \mathrm{L}$; aspartate aminotransferase (AST), $30 \mathrm{U} / \mathrm{L}$; alanine aminotransferase (ALT), $28 \mathrm{U} / \mathrm{L}$. Her chest X-ray and computed tomography (CT) on admission revealed no remarkable change including pneumonia, and her abdominal CT revealed slight hepatomegaly and splenomegaly. Neither influenza A nor B antigens were detected, and Mycoplasma pneumonia antigen was not detected. Her hepatitis B surface antigen and hepatitis $C$ antibody tests

Table 1 Clinical data after primary Cytomegalovirus infection in this subject

\begin{tabular}{|c|c|c|c|c|c|}
\hline Variable & Result & Reference range & Variable & Result & $\begin{array}{l}\text { Reference } \\
\text { range }\end{array}$ \\
\hline Peripheralblood & & & Blood biochemistry & & \\
\hline White blood cells $(/ \mu \mathrm{L})$ & 1710 & $3300-8600$ & Total protein (g/dL) & 6.3 & $6.6-8.1$ \\
\hline Neutrophils (\%) & 76.0 & $52.0-80.0$ & Albumin $(\mathrm{g} / \mathrm{dL})$ & 3.6 & $4.1-5.1$ \\
\hline Eosinophils (\%) & 0.0 & $1.0-5.0$ & Globulin (g/dL) & 2.7 & $2.2-3.4$ \\
\hline Basophils (\%) & 0.0 & $0.0-1.0$ & Cholinesterase (U/L) & 163 & $240-486$ \\
\hline Monocytes (\%) & 5.0 & $1.0-6.0$ & Total bilirubin (mg/dL) & 2.7 & $0.4-1.5$ \\
\hline Lymphocytes (\%) & 18.0 & $20.0-40.0$ & Direct bilirubin (\%) & 11 & $30-52$ \\
\hline Atypical lymphocytes (\%) & 1.0 & & $\mathrm{AST}(\mathrm{U} / \mathrm{L})$ & 30 & $13-30$ \\
\hline Red blood cells $\left(\times 10^{4} / \mu \mathrm{L}\right)$ & 429 & $435-555$ & $\operatorname{ALT}(U / L)$ & 28 & $10-42$ \\
\hline Hemoglobin (g/dL) & 12.8 & $13.7-16.8$ & $\mathrm{LDH}(\mathrm{U} / \mathrm{L})$ & 221 & $124-222$ \\
\hline Platelets $\left(\times 10^{4} / \mu \mathrm{L}\right)$ & 8.7 & $15.8-34.8$ & $A L P(U / L)$ & 276 & $106-322$ \\
\hline Congealing fibrinogenolysis system & & & Y-GTP $(U / L)$ & 78 & $13-64$ \\
\hline PT (seconds) & 14.3 & $9.3-12.5$ & BUN (mg/dL) & 8 & $8-20$ \\
\hline PT-INR & 1.25 & $0.85-1.13$ & Creatinine (mg/dL) & 0.69 & $0.65-1.07$ \\
\hline PT activity (\%) & 66.5 & $80.7-125.2$ & Uric acid (mg/dL) & 5.2 & $2.6-5.5$ \\
\hline APTT (seconds) & 46.7 & $26.9-38.1$ & Amylase $(\mathrm{U} / \mathrm{L})$ & 89 & $44-132$ \\
\hline Fibrinogen (mg/dL) & 263 & $160-380$ & Creatinine kinase (U/L) & 62 & $41-153$ \\
\hline Urinary test & & & Plasma glucose (mg/dL) & 91 & \\
\hline Urinary pH & 7.0 & $5.0-7.5$ & Total cholesterol (mg/dL) & 168 & $142-248$ \\
\hline Urinary protein & \pm & - & LDL cholesterol (mg/dL) & 89 & $65-139$ \\
\hline Urinary sugar & - & - & HDL cholesterol (mg/dL) & 57 & $40-90$ \\
\hline Urinary ketone body & - & - & Triglyceride (mg/dL) & 71 & $40-149$ \\
\hline Urinary blood & \pm & - & Sodium (mmol/L) & 135 & $138-145$ \\
\hline \multirow[t]{4}{*}{ Urinary bacteria } & \pm & - & Potassium (mmol/L) & 3.7 & $3.6-4.8$ \\
\hline & & & Chloride (mmol/L) & 102 & $101-108$ \\
\hline & & & $\operatorname{CRP}(\mathrm{mg} / \mathrm{dL})$ & 3.92 & $<0.14$ \\
\hline & & & Procalcitonin (ng/mL) & 0.39 & $0.00-0.05$ \\
\hline
\end{tabular}

PT prothrombin time, INR international normalized ratio, APTT activated partial thromboplastin time, AST aspartate aminotransferase, $A L T$ alanine aminotransferase, $L D H$ lactate dehydrogenase, $A L P$ alkaline phosphatase, $\gamma$-GTP $\gamma$-glutamyl transpeptidase, $B U N$ blood urea nitrogen, $L D L$ low-density lipoprotein, $H D L$ high-density lipoprotein, CRP C-reactive protein 
were negative. Human immunodeficiency virus (HIV) antigen/antibody test was negative (cutoff index $<0.3$ ). Her Treponema pallidum hemagglutination (TPHA) was negative. Pathogenic bacteria were not detected, although small amounts of Corynebacterium sp. and Gram-positive cocci were detected in urine culture. We started antibiotic therapy (500 $\mathrm{mg} /$ day of levofloxacin), because we failed to rule out a bacterial infection due to an elevated CRP level. She was suspected of having a bladder infection by her previous doctor, and in fact she had bacteriuria. Her virus antibodies were as follows: EBV (EBV) anti-viral capsid antigen (VCA) immunoglobulin M (IgM) antibody, 0.2 (-) (fluorescent antibody method [FA], SRL Inc., Tokyo); EBV anti-VCA immunoglobulin G (IgG) antibody, 0.2 (-) (FA, SRL Inc., Tokyo); EBV anti-EBV nuclear antigen (EBNA) Immunoglobulin (Ig) G antibody, 0.1 (-) (FA, SRL Inc., Tokyo); CMV IgM antibody, $3.89(+)$ (enzyme immunoassay (EIA), SRL Inc., Tokyo); CMV IgG antibody, 24.0 (+) (EIA, SRL Inc., Tokyo). Based on these findings, we finally arrived at a diagnosis of primary CMV infection. Four days later, her temperature was reduced to under $37^{\circ} \mathrm{C}$, and about 1 week later, her clinical symptoms disappeared and laboratory data including leukocytopenia and liver dysfunction were improved (Fig. 1). She was discharged 10 days after admission. She did not experience another abnormal physical condition after discharge, but we continued to observe her condition on an outpatient basis. Therefore, we checked her virus antibodies. Her CMV IgM antibody became negative about 3 months later, and we confirmed that her CMV infection was a prior infection pattern.

About 5 months later, she again experienced fever and lymph node enlargement at the posterior cervical region and visited our emergency room. She had no symptoms other than high fever and lymph node enlargement, and there were no findings on physical or neurological examination. Her vital signs were as follows: heart rate 85 beats/minute, blood pressure $98 / 56 \mathrm{mmHg}$, and temperature $38.9^{\circ} \mathrm{C}$. Table 2 shows the laboratory data at that time. Atypical lymphocytes were detected and the CRP level was slightly increased: WBC count, $6860 / \mu \mathrm{L}$ (neutrophils 19.0\%; monocytes $6.0 \%$; lymphocytes $73.0 \%$; atypical lymphocytes $2.0 \%$ ); CRP, $0.57 \mathrm{mg} / \mathrm{dl}$. Furthermore, she had severe liver dysfunction: $\gamma$-GTP, $291 \mathrm{U} / \mathrm{L}$; ALP, 1060 U/L; AST, 379 U/L; ALT 381 U/L. We thought

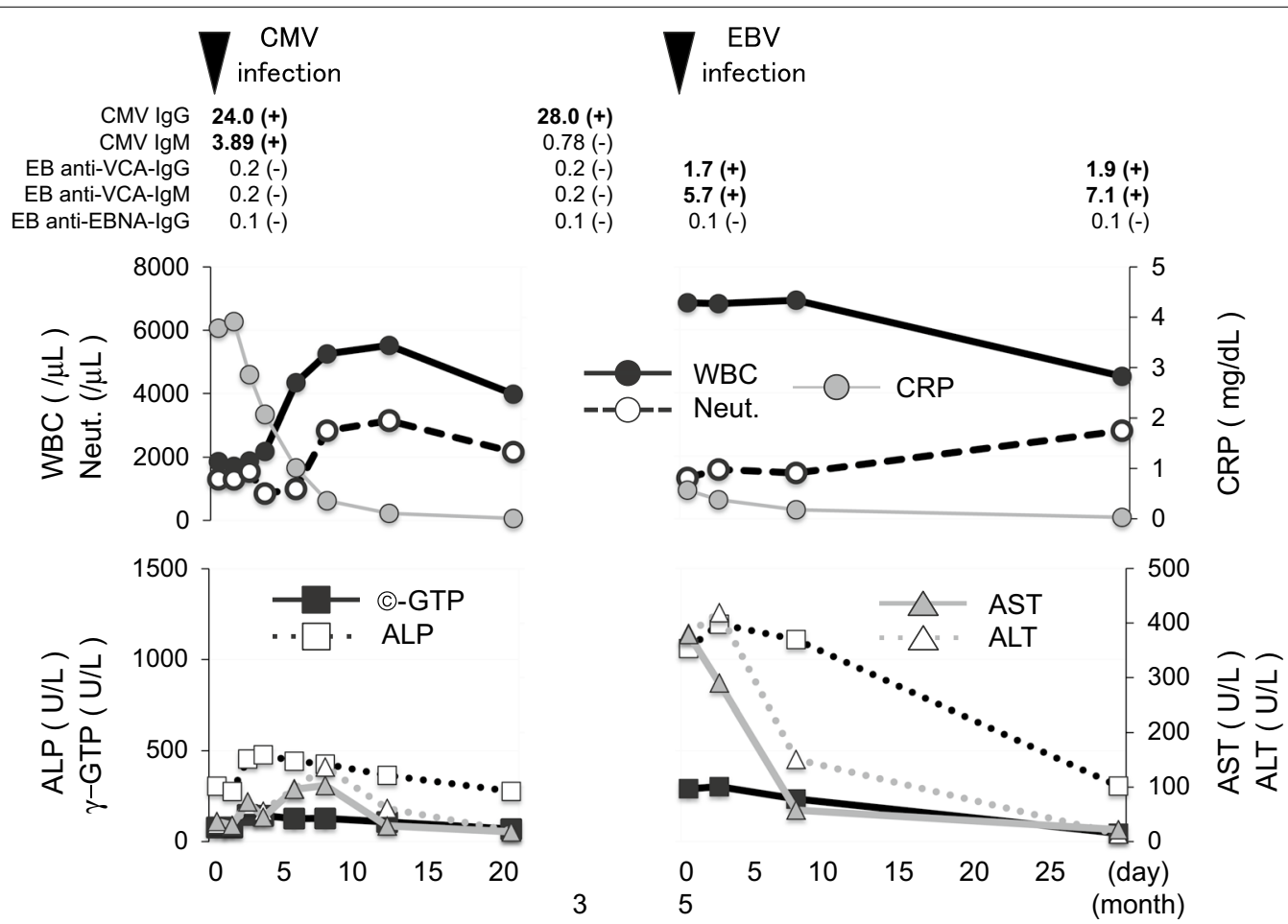

Fig. 1 Clinical time course in this patient. Decreased WBC and increased CRP levels were observed after CMV infection, and mild liver dysfunction was also detected. The data for various virus antibodies showed a primary CMV pattern, and EBV antibody was negative at that time. About 5 months later, she had primary EBV infection. She had very severe liver dysfunction after EBV infection compared with after CMV infection. CMV Cytomegalovirus, EBV Epstein-Barr virus, WBC white blood cell, CRP C-reactive protein, $\gamma$-GTP $\gamma$-glutamyl transpeptidase, ALP alkaline phosphatase, AST aspartate aminotransferase, ALT alanine aminotransferase 
Table 2 Clinical data after primary Epstein-Barr virus infection in this subject

\begin{tabular}{|c|c|c|c|c|c|}
\hline Variable & Result & Reference range & Variable & Result & $\begin{array}{l}\text { Reference } \\
\text { range }\end{array}$ \\
\hline Peripheral blood & & & Blood biochemistry & & \\
\hline 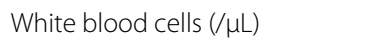 & 6860 & $3300-8600$ & Total protein (g/dL) & 7.4 & $6.6-8.1$ \\
\hline Neutrophils (\%) & 19.0 & $52.0-80.0$ & Albumin $(\mathrm{g} / \mathrm{dL})$ & 4.0 & $4.1-5.1$ \\
\hline Eosinophils (\%) & 0.0 & $1.0-5.0$ & Globulin (g/dL) & 3.4 & $2.2-3.4$ \\
\hline Basophils (\%) & 0.0 & $0.0-1.0$ & Cholinesterase (U/L) & 182 & $240-486$ \\
\hline Monocytes (\%) & 6.0 & $1.0-6.0$ & Total bilirubin (mg/dL) & 1.9 & $0.4-1.5$ \\
\hline Lymphocytes (\%) & 73.0 & $20.0-40.0$ & AST $(U / L)$ & 379 & $13-30$ \\
\hline Atypical lymphocytes (\%) & 2.0 & & $\operatorname{ALT}(\mathrm{U} / \mathrm{L})$ & 381 & $10-42$ \\
\hline Red blood cells $\left(\times 10^{4} / \mu \mathrm{L}\right)$ & 686 & $435-555$ & $\mathrm{LDH}(\mathrm{U} / \mathrm{L})$ & 650 & $124-222$ \\
\hline Hemoglobin (g/dL) & 13.6 & $13.7-16.8$ & $\operatorname{ALP}(\mathrm{U} / \mathrm{L})$ & 1060 & $106-322$ \\
\hline Platelets $\left(\times 10^{4} / \mu \mathrm{L}\right)$ & 15.5 & $15.8-34.8$ & $\gamma-G T P(U / L)$ & 291 & $13-64$ \\
\hline Congealing fibrinogenolysis system & & & BUN (mg/dL) & 10 & $8-20$ \\
\hline PT (seconds) & 11.9 & $9.3-12.5$ & Creatinine (mg/dL) & 0.62 & $0.65-1.07$ \\
\hline PT-INR & 1.03 & $0.85-1.13$ & Uric acid (mg/dL) & 4.8 & $2.6-5.5$ \\
\hline PT activity (\%) & 94.9 & $80.7-125.2$ & Plasma glucose (mg/dL) & 140 & \\
\hline APTT (seconds) & 39.6 & $26.9-38.1$ & Total cholesterol (mg/dL) & 182 & $142-248$ \\
\hline \multirow[t]{4}{*}{ Fibrinogen (mg/dL) } & 229 & $160-380$ & Sodium (mmol/L) & 137 & $138-145$ \\
\hline & & & Potassium (mmol/L) & 3.9 & $3.6-4.8$ \\
\hline & & & Chloride (mmol/L) & 101 & $101-108$ \\
\hline & & & CRP (mg/dL) & 0.57 & $<0.14$ \\
\hline
\end{tabular}

PT prothrombin time, INR international normalized ratio, APTT activated partial thromboplastin time, AST aspartate aminotransferase, $A L T$ alanine aminotransferase, $L D H$ lactate dehydrogenase, $A L P$ alkaline phosphatase, $\gamma$-GTP $\gamma$-glutamyl transpeptidase, $B U N$ blood urea nitrogen, $C R P C$-reactive protein

that it would be better to hospitalize her and start drip infusion of monoammonium glycyrrhizinate glycine for severe liver dysfunction, but she did not agree to the hospitalization. Therefore, instead we started $60 \mathrm{~mL} /$ day of monoammonium glycyrrhizinate glycine on an outpatient basis. At that time, we suspected viral infection and thus we did not administer antibiotics. She visited our office for drip infusion of monoammonium glycyrrhizinate glycine every day, and about 5 days later the high fever disappeared. About 1 week later, her clinical symptoms and laboratory data were improved (Fig. 1) and we stopped the therapy with monoammonium glycyrrhizinate glycine. At that time, her EBV antibodies were as follows: EBV anti-VCA IgM antibody, $1.7(+)$;
EBV anti-VCA IgG antibody, 5.7 (+); EBV anti-EBNA IgG antibody, 0.1 (-). Therefore, we finally diagnosed her condition as primary EBV infection.

In addition, we checked the antibodies for both CMV and EBV infection several times in this patient, and Table 3 shows the time course for these antibodies. Such time course clearly shows that this patient had primary EBV infection shortly after primary CMV infection.

\section{Discussion}

Herein, we report a healthy adult Japanese woman with primary EBV infection shortly after primary CMV infection. It is difficult to diagnose such infectious diseases based only on subjective symptoms such as a high fever,

Table 3 Time course of various antibodies for both CMV and EBV in this patient

\begin{tabular}{|c|c|c|c|c|c|}
\hline Virus antibody & $\begin{array}{l}\text { Just after primary } \\
\text { CMV infection }\end{array}$ & $\begin{array}{l}3 \text { months after } \\
\text { CMV infection }\end{array}$ & $\begin{array}{l}5 \text { months after } \mathrm{CMV} \text { infection and } \\
\text { just after primary EBV infection }\end{array}$ & $\begin{array}{l}6 \text { months after } \\
\text { CMV infection }\end{array}$ & $\begin{array}{l}\text { Reference } \\
\text { range }\end{array}$ \\
\hline CMV IgG antibody & $24.0(+)$ & $28.0(+)$ & N/A & N/A & $<0.2$ \\
\hline CMV IgM antibody & $3.89(+)$ & $0.78(-)$ & N/A & N/A & $<0.80$ \\
\hline EBV anti-VCA IgG antibody & $0.2(-)$ & $0.2(-)$ & $1.7(+)$ & $1.9(+)$ & $<0.5$ \\
\hline EBV anti-VCA IgM antibody & $0.2(-)$ & $0.2(-)$ & $5.7(+)$ & $7.1(+)$ & $<0.5$ \\
\hline EBV anti-EBNA IgG antibody & $0.1(-)$ & $0.1(-)$ & $0.1(-)$ & $0.1(-)$ & $<0.5$ \\
\hline
\end{tabular}

CMV Cytomegalovirus, EBV Epstein-Barr virus, VCA viral capsid antigen, EBNA EBV nuclear antigen, N/A not applicable 
pharyngitis and lymphadenopathy. IM and MLI are major illnesses which are caused by EBV and CMV, respectively, and are often accompanied by such symptoms [2, 9]. Adults with primary EBV or CMV infection often experience serious symptoms, although such infection in childhood is generally subclinical with either virus. Our patient had almost the same symptoms, including high fever, pharyngitis and lymphadenopathy, after both CMV and EBV infection. However, she had decreased WBC and high CRP after CMV infection. In contrast, WBC and CRP levels were not altered after EBV infection. In addition, she had very severe liver dysfunction after EBV infection compared with after CMV infection. Some reports have compared subjects with EBV infection and those with CMV infection. However, it is very interesting to compare subjective symptoms and/or clinical data after EBV and CMV infection in the same patient within a short period of time. In general, CMV infection affects patients who are 10-15 years older and who have milder lymphadenopathy and pharyngitis compared with EBV infection, but more frequent and serious hepatitis is observed after CMV infection [3-5]. In clinical practice, however, it is very difficult to distinguish EBV infection from CMV infection without checking various antibodies for these viruses. Indeed, our patient was not diagnosed based only on subjective symptoms, physical examination and laboratory data without tests of such virusrelated antibodies.

It has been reported that in industrialized societies, individuals with lower socioeconomic status are more easily infected with EBV and at younger ages than those in affluent groups [10]. It is also well known that EBV and CMV are common opportunistic infections in immunocompromised conditions such as HIV infection, but not in healthy adult subjects [11]. In addition, co-infection with EBV and CMV has been reported mainly in children $[12,13]$. However, it is difficult to determine which findings (e.g. liver dysfunction) are mainly due to EBV and/ or CMV infection. Therefore, it is interesting to compare such symptoms and/or clinical data in the same patient. Also, it was pointed out recently that both EBV and CMV antibody positivity rates are lower in Japanese healthy adults. Both EBV and CMV infection are common in Japan, although in most cases they remain latent throughout human life. It was previously reported that many Japanese were infected with EBV in infancy as subclinical infection and with CMV in the perinatal period as subclinical infection. However, the age of first infection of EBV and CMV has recently clearly been increasing. In addition, it seems that the first infection of EBV and CMV would be increased in the future, although the reported cases are few and the case of overt infection is rare. Such phenomena have attracted much attention, and we are very concerned that the decrease in such rates would lead to an increase in EBV and/or CMV infection in the future.

There are limitations in this case report. First, we did not perform EBV and CMV polymerase chain reaction (PCR), and the diagnosis was based mainly on the serology data. Distinguishing current infection from past infection is more commonly and more easily accomplished through virus antibody tests [14]. Our patient happened to have two infections; the primary EBV infection manifested shortly after the primary CMV infection. Since the PCR method confirms current active infection [15], in this case, the serology method would have made it easier to understand her pathology. Second, there are some reports of cross-reactivity and false positivity and negativity [16]. Both EBV and CMV belong to the herpes virus group, and IgM-type antibodies of CMV are detected in about one-third of cases of initial EBV infection $[17,18]$. While it is known that cross-reactivity and false positivity and negativity cause problems in patients with two infections at the same time, there was some time lag (about 5 months) between the two infections in this case. Therefore, we think that there is no problem with cross-reactivity or false positivity/negativity in this case. Furthermore, in her first virus infection, her antibodies showed a primary CMV infection pattern [CMV IgM antibody, (+); CMV IgG antibody, $(+)$ ], although her EBV infection antibody was all negative. However, in her second virus infection, her antibodies showed a primary EBV infection pattern [EBV anti-VCA IgM antibody, $(+)$; EBV anti-VCA IgG antibody, (+); EBV anti-EBNA IgG antibody, (-)]. If her primary EBV infection and primary CMV infection manifested at the same time, as was the case in previous reports [11, 12], cross-reactivity and false positivity/negativity would have definitely remained controversial. Third, we did not check the patient's partner for antibodies to EBV and CMV, but since he was older than the patient, we assume that he was already infected with both EBV and CMV, just as the average Japanese are already infected.

\section{Conclusions}

We should bear in mind that primary EBV infection and/ or primary CMV infection is possible when patients have symptoms such as high fever, pharyngitis and lymphadenopathy, even in healthy adults.

\section{Acknowledgements \\ Not applicable.}

Authors' contributions

KK and TA researched the data and wrote the manuscript. TU, RS, SI, FK and MK researched the data and contributed to the discussion. HKaw, HKan and TK

reviewed the manuscript. All authors read and approved the final manuscript. 


\section{Funding}

There was no funding for this work.

\section{Availability of data and materials}

Not applicable.

\section{Declarations}

\section{Ethics approval and consent to participate}

Not applicable.

\section{Consent for publication}

Written informed consent was obtained from the patient for publication of this case report and any accompanying images. A copy of the written consent is available for review by the Editor-in-Chief of this journal.

\section{Competing interests}

The authors declare that they have no competing interests.

\section{Author details}

'Department of General Internal Medicine 1, Kawasaki Medical School, 2-6-1 Nakasange, Kita-ku, Okayama 700-8505, Japan. ${ }^{2}$ Department of General Internal Medicine 2, Kawasaki Medical School, Okayama 700-8505, Japan. ${ }^{3}$ Department of Diabetes, Metabolism and Endocrinology, Kawasaki Medical School, Kurashiki 701-0192, Japan.

Received: 13 November 2020 Accepted: 23 March 2021 Published online: 03 May 2021

\section{References}

1. Hallee TJ, Evans AS, Niederman JC, Brooks CM, Voegtly JH. Infectious mononucleosis at the United States Military Academy. A prospective study of a single class over four years. Yale J Biol Med. 1974;47:182-95.

2. Hurt C, Tammaro D. Diagnostic evaluation of mononucleosis-like illnesses. Am J Med. 2007;120(911):e1-8.

3. Ishii T, Sasaki Y, Maeda T, Komatsu F, Suzuki T, Urita Y. Clinical differentiation of infectious mononucleosis that is caused by Epstein-Barr virus or cytomegalovirus: a single-center case-control study in Japan. J Infect Chemother. 2019;25:431-6.

4. Taylor GH. Cytomegalovirus. Am Fam Phys. 2003;67:519-24.

5. Ebell MH. Epstein-Barr virus infectious mononucleosis. Am Fam Phys. 2004:70:1279-87.

6. Dunmire SK, Hogquist KA, Balfour HH. Infectious mononucleosis. Curr Top Microbiol Immunol. 2015:390:211-40.
7. Ebell MH, Call M, Shinholser J, Gardner J. This patient have infectious mononucleosis?: The rational clinical examination systematic review. JAMA. 2016:315:1502-9.

8. Guerrero-Ramos A, Patel M, Kadakia K, Haque T. Performance of the architect EBV antibody panel for determination of Epstein-Barr virus infection stage in immunocompetent adolescents and young adults with clinical suspicion of infectious mononucleosis. Clin Vaccine Immunol. 2014;21:817-23.

9. Medović R, Igrutinović Z, Radojević-Marjanović R, Marković S, Rasković Z, Simović A, et al. Clinical and laboratory differences between Epstein-Barr and cytomegalovirus infectious mononucleosis in children. Srp Arh Celok Lek. 2016;144:56-62.

10. Nye FJ. Social class and infectious mononucleosis. J Hyg (Lond). 1973;71:145-9.

11. Post JJ, Chan MK, Whybin LR, Shi Q, Rawlinson WD, Cunningham P, et al. Positive Epstein-Barr virus and cytomegalovirus IgM assays in primary HIV infection. J Med Virol. 2011;83:1406-9.

12. Olson D, Huntington MK. Co-infection with cytomegalovirus and Epstein-Barr virus in mononucleosis: case report and review of literature. SD Med: J SD State Med Assoc. 2009:62:349-54.

13. Saghafian-Hedengren S, Sohlberg E, Theorell J, Carvalho-Queiroz C, Nagy $\mathrm{N}$, Persson JO, et al. Epstein-Barr virus coinfection in children boosts cytomegalovirus-induced differentiation of natural killer cells. J Virol. 2013;87:13446-55.

14. Eggers M, Bäder U, Enders G. Combination of microneutralization and avidity assays: improved diagnosis of recent primary human cytomegalovirus infection in single serum sample of second trimester pregnancy. J Med Virol. 2000;60:324-30.

15. Kimura H, Morita M, Yabuta Y, Kuzushima K, Kato K, Kojima S, et al. Quantitative analysis of Epstein-Barr virus load by using a real-time PCR assay. J Clin Microbiol. 1999:37:132-6.

16. Horwitz CA, Henle W, Henle G, Snover D, Rudnick H, Balfour HH Jr, et al. Clinical and laboratory evaluation of cytomegalovirus-induced mononucleosis in previously healthy individuals. Report of 82 cases. Medicine (Baltimore). 1986:65:124-34.

17. Hanshaw JB, Niederman JC, Chessin LN. Cytomegalovirus macroglobulin in cell-associated herpesvirus infections. J Infect Dis. 1972;12:304-6.

18. Schmitz H. Detection of immunoglobulin $M$ antibody to EpsteinBarr virus by use of an enzyme-labeled antigen. J Clin Microbiol. 1982;16:361-6.

\section{Publisher's Note}

Springer Nature remains neutral with regard to jurisdictional claims in published maps and institutional affiliations.

Ready to submit your research? Choose BMC and benefit from:

- fast, convenient online submission

- thorough peer review by experienced researchers in your field

- rapid publication on acceptance

- support for research data, including large and complex data types

- gold Open Access which fosters wider collaboration and increased citations

- maximum visibility for your research: over 100M website views per year

At $\mathrm{BMC}$, research is always in progress.

Learn more biomedcentral.com/submissions 